\title{
TURNING FISH SOUP BACK INTO FISH: THE WICKED PROBLEM OF AFRICAN COMMUNITY LAND RIGHTS
}

\author{
Robert Home* \\ Faith Kabata**
}

\begin{abstract}
Africa's postcolonial disputes over community land rights are a "wicked" problem, not evil, but resistant to resolution. This article investigates three such disputes in Kenya (Endorois, Ogiek and Nubian community) where the African Commission and Court of Human and Peoples' Rights have determined in the communities' favour but the implementation is not progressing, both because of opposition by the state and the complex and long-standing nature of the cases. The legal history of colonial trust lands and recent community land legislation is discussed, the three key cases are summarized, and issues of indigenous people's status, admissibility and respondent government discussed in relation to the UN Declarations on Rights of Indigenous Peoples (1987), Right to Development (1986), and Land Issues (2009). Practical and political aspects of implementing the determinations are examined, and recommendations proposed.
\end{abstract}

Keywords: Indigenous people's rights; Endorois; Ogiek; Nubian community; Kibera; land law reform; African Union enforcement.

DOI: https://dx.doi.org/10.4314/jsdlp.v9i2.2

\section{INTRODUCTION}

A Russian adage, dating from the country's post-Communist transformation in the 1990s says, "it is easy to turn fish into fish soup, less easy to turn fish soup back into fish". ${ }^{1}$ This could also apply to

* MA PhD MRTPI Emeritus Professor in Land Management, Anglia Ruskin University (UK). Email Robert.home@anglia.ac.uk.

$* * \quad$ LL.B, LL.M LL.D Law Lecturer, Kenyatta University School of Law (Kenya) Email: kabata.faith@ku.ac.ke

1 R. Home et al. Turning Fish Soup into Fish: Towards New Land and Property Markets in Bulgaria (Surveyors Publications 1996). 
Africa's postcolonial land questions, which can be seen as a "wicked" problem. Wicked here means, not evil, but resistant to resolution, difficult or impossible to solve because of complex interdependencies, so that efforts to solve one aspect may reveal or create other problems. ${ }^{2}$

Indigenous peoples' land rights are generating a growing number of legal cases (in both national and international courts) and attracting substantial academic literature, especially since the UN Declaration on the Rights of Indigenous Peoples (1987). ${ }^{3}$ Uncertainty over the term "indigenous peoples" in Africa was addressed by a working party of the African Union (AU) in 2005, yet the uncertainty continues. ${ }^{4}$ While some African countries adjudicate such land cases in their own courts, for instance, Botswana, Uganda and South Africa, ${ }^{5}$ the AU judicial system has supported indigenous peoples' land claims in several determinations as a violation of the right to property under Article 14 of the Banjul Charter. That charter was also the first international human rights

2 Jeff Conklin Dialogue Mapping: Building Shared Understanding of Wicked Problems (Wiley 2005).

3 Randall Abate and Elizabeth Ann Kronk, Climate Change and Indigenous Peoples: The Search for Legal Remedies (Edward Elgar 2013); Peter H. Russell, Recognising Aboriginal Title: The Mabo Case and Indigenous Resistance to English-settler Colonialism Sydney (UNSW Press 2006); Patrick Thornberry, Indigenous Peoples and Human Rights (Manchester University Press 2002); Laura Westra, Environmental Justice and the Rights of Indigenous Peoples: International and Domestic Legal Perspectives (Earthscan 2013). Articles: Jeremie Gilbert (2007) "Historical Indigenous Peoples' Land Claims: A Comparative and International Approach to the Common Law Doctrine on Indigenous Title" International and Comparative Law Quarterly 56 (3). 583-611; 57; Rebecca Hardin and Kelly Askew, "Claims, Rights, Voices, and Spaces in the Global Indigenous Peoples Movement" (2016) 2 JLProp \& Soc'y 49; C. Tennant, "Indigenous Peoples, International Institutions, and the International Legal Literature from 19451993" (1994) 16(1) Human Rights Quarterly 1. Most land cases reported in the Commonwealth Law Bulletin in the last twenty years relate to indigenous people's land rights.

4 African Union Report of Working Group of Experts on Indigenous Populations/ Communities (IWGIA) (Banjul 2005) 93; Douglas Sanders "Indigenous Peoples: Issues of Definition" (1999) 8(1) International Journal of Cultural Property 4.

5 T. M. Chan "The Richtersveld Challenge: South Africa Finally Adopts Aboriginal Title" in. Diana Vinding and Robert K Hitchcock (eds) Indigenous People's Rights in Southern Africa (IWGIA, 2004); M Barry "Now Another Thing Must Happen" (2004) 20 South African Journal of Human Rights 355; Albert Kwokwo Barume, Land Rights of Indigenous Peoples in Africa: With Special Focus On Central, Eastern and Southern Africa (Copenhagen International Work Group for Indigenous Affairs, 2010). 
instrument to recognize the right to development as a discrete right. ${ }^{6}$ Communities without indigenous people status may also make successful claims, notably the Nubian community in Kenya, about denial of citizenship and registration, as well as rights to property, especially in Kibera (Nairobi), "Africa's largest slum".

Three recent cases succeeded in the African Court (African Court) and the African Commission on Human and Peoples' Rights (African Commission). All related to Kenya, which has a distinctive history of colonial settler displacement of Africans and postcolonial attempts at land reform. ${ }^{7}$ Two of the cases related to groups accepted as indigenous peoples (the Endorois and Ogiek), while the third involved descendants of Nubian soldiery that served the British colonial power. All three communities were reduced to conditions of poverty and precarity because of state actions over the decades. The Endorois case involved wildlife protection, tourism and a proposed World Heritage site; the Ogiek case involved forests and an important river catchment area; the Nubian community case raised issues similar to those in the recent much-publicised "Windrush generation" in Britain. ${ }^{8}$

Drawing examples from complex cases on land rights in Kenya, this article discusses the difficulties in implementing the judgments of the African Court and African Commission concerning land allocation in African countries. After this introduction, section 2 examines the legal history relating to land in Kenya and summarizes the three cases

6 OAU Doc AB/LEG/67/3 (1981). Article 14 states: "The right to property shall be guaranteed. It may only be encroached upon in the interest of public need or in the general interest of the community and in accordance with the provisions of appropriate laws". The Commission recognizes land as property for the purposes of Article 14, which includes the right to have access to one's property and not to have it invaded or encroached upon.

7. Another long-running and much-publicized dispute (not discussed here) relates to displacement of the Maasai (an iconic tourist attraction) in Kenya and Tanzania, who claimed some 70 per cent of the former White Highlands as "properly ours". Parselelo Kantai,. "In the Grip of the Vampire State: Maasai Land Struggles in Kenyan Politics" (2007) 1:1, Journal of Eastern African Studies 107; Lotte Hughes, Moving the Maasai: A Colonial Misadventure (Palgrave 2006).

8 These are people who came to the UK from the Commonwealth countries after the Second World War and before 1973, and have been treated as if they were in the country illegally despite being lawfully resident for many decades. Some have lost their homes and jobs, been refused healthcare, pensions and access to social security, even deported from the UK; many of their children and spouses have also been affected. House of Commons Home Affairs Committee The Windrush Generation (2018) Sixth Report of Session 2017-19. 
and the current progress or non-progress with implementing the judgments of the African Court and African Commission against a reluctant and obstructive state. Section 3 investigates some of the issues raised by the cases, and section 4 the challenges for implementation of the determinations. Section 5 concludes with some recommendations for future action.

\section{KENYA'S COLONIAL AND POSTCOLONIAL ERA LAND LAWS}

Before independence, Kenyan land law was dominated by the politics of white settler land taking, and denial of access to land was at the root of the anti-colonial struggles that resulted in Kenya's achievement of independence from Britain in 1963. The country's tangled legacy of land laws - "the land question" - has in the last decade been addressed by land law reform, but the appropriation of public land for private benefit has continued by the new African elites.

Kenya's colonial era effectively began with the 1895 British government's declaration of the East African Protectorate (later renamed the Kenya colony). ${ }^{9}$ The Crown Lands Ordinance 1915 vested virtually all land in the name of the crown, and the Government Lands Ordinance of the same year empowered the colonial administration to grant such crown land to white settlers or companies on 999-year leases (in effect freeholds). Land grants to settlers were supported by an official register of titles, and by 1926 totalled 3 million acres $\left(12,000 \mathrm{~km}^{2}\right)$ of the best farming and forest land. ${ }^{9}$

After the Devonshire Declaration of 1923 that African interests were to be paramount, ${ }^{10}$ the Native Lands Trust Ordinance 1930 created land reserves for the African or "native" population, where customary law applied. Individual leases could still be granted, and the colonial administration reserved the right to set apart land for "public purposes", which included such uses as mining, forestry and townships. Native Africans were considered to be tenants of the Crown with only

9 Kenya Return Showing Crown Grants of land on over 5000 Acres in Extent (1926) MPK Sorenson, Origins of European Settlement in Kenya (OUP 1968); Smokin Wanjala, "Land Ownership and Use in Kenya: Past, Present And Future" in his Essays on Land Law: The Reform Debate in Kenya (University of Nairobi 2000) 27.

10 Robert Maxon, (1991) 18 History in Africa “The Devonshire Declaration" 259. 
temporary occupancy rights and could be classed as squatters if on white settler land without the owner's consent. ${ }^{11}$ Subsequently, in an attempt to counter the Mau-Mau insurgency, the Swynnerton Report recommended that an African landed class be created by facilitating individual African ownership in the tribal trust lands (as the reserves were renamed). This attempt to slow down African demands led to the Registered Lands Act 1963 (passed just before independence), followed by a subsequent Land Adjudication Act 1968, which provided for the ascertainment and recording of rights and interests in Trust land through systematic adjudication, a process similar to the adjudication of enclosure claims in nineteenth-century Britain. ${ }^{12}$

After independence, the Kenyan government continued to grant individual titles, while excluding indigenous communities from reclaiming land that had been taken from them during colonial rule. "The land owning ethic has now become a national mania whereby everyone dreams of owning land." 13 President Kenyatta's government encouraged the establishment of private land-buying companies, often headed by prominent politicians, and sold or leased lands in the former White Highlands to these companies, who in turn subdivided them among individual shareholders or sold them on to public corporations at inflated values. This preference for private land ownership privileged sedentary agriculture over pastoralism and hunter-gathering as practised by Kenya's marginalized indigenous ethnic groups. ${ }^{14}$ Meanwhile, Kenya's population grew rapidly from 8 million at independence in 1963 to 51 million by 2017, increasing pressures upon the land, both urban and rural.

The 1970 Trust Land Act transferred former native reserve land to so-called county councils, to be held in trust and administered by them

11 Isaka Wainaina wa Gathomo and Kamau wa Gathomo v Murito wa Indangara, Nganga wa Murito and Attorney General (1922-23) 9(2) KLR 102, cited in George Mukundi Wachira “Vindicating Indigenous Peoples' Land Rights in Kenya” (LLD thesis University of Pretoria 2008) 61.

12 Simon Coldham, "The Effect of Registration of Title Upon Customary Land Rights in Kenya" (1978) 22 Journal of African Law 110; Catherine Boone, "Land Conflict and Distributive Politics in Kenya" (2012) 55(1) African Studies Review 75; MPK Sorenson, Origins of European Settlement in Kenya (OUP 1968).

13 Smokin C Wanjala, Land Law and Disputes in Kenya (OUP 1990) 7.

14 Celestine Musembi \& P Kameri-Mbote "Mobility, Marginality and Tenure Transformation in Kenya: Explorations of Community Land Rights in Law And Practice" (2013)17 Nomadic Peoples 6. 
under customary law, but such land could be converted into individual titles or "set apart" for public purposes as the former "colonial masters" had done, and as happened to much community land. ${ }^{15}$ The Land (Group Representatives) Act 1968 and the Trust Land Act 1970 provided only a weak regime for community land rights until the Constitution of 2010, further complicated by laws on natural resources such as wildlife, forests and water.

The national debate following the electoral violence and mass displacements in 2007-2008 led to a new Constitution in $2010 .{ }^{16}$ Its Land and Environment chapter sought to reform land laws with an ostensibly progressive legal framework that addressed such issues as an abuse of public land for private benefit, insecure tenure for the majority population, and the multiplicity of legal regimes. Stated principles for land use and management included equitable access to land, security of land rights, elimination of gender discrimination, and sustainable management of land resources. All land was vested in the people of Kenya collectively under three land tenure systems (public, private and community), supposedly of equal status.

Community land vested in communities rather than the discredited former county councils is defined under the Constitution as: (a) land registered in the name of group representatives (i.e. group ranches); (b) land lawfully transferred to a specific community; (c) any other land declared community land by an Act of Parliament; and (d) land lawfully held, managed or used by specific communities as community forests, grazing areas or shrines, ancestral lands and lands traditionally occupied by hunter-gatherer communities or lawfully held as trust land by county governments. The subsequent Community Land Act 2016 added provisions relating to communities of ethnicity, culture or similar community of interest, a broader interpretation that included persons with a common ancestry, unique mode of livelihood, socio-economic or other common interest, geographical or ecological space; this could include communities occupying a particular geographical space such

15 Report of the Commission of Inquiry into Illegal/Irregular Allocation of Public Land in Kenya, 2004 (Ndung'u Report).

16 Kenya Constitution (Attorney General 2010); Solomon A Dersso, Taking Ethnocultural Diversity Seriously in Constitutional Design: A Theory of Minority Rights for Addressing Africa's Multiethnic Challenge (Martinus Nijhoff 2012). 
as Kibera. ${ }^{17}$ The Act creates potentially extensive powers for communities: to make laws for community land, protecting customary rights previously held, providing for derivative rights for individuals, families and groups formed by community members, registration of title for certain parts, and gender equality in the treatment of applications. Unfortunately, the political will to operationalize such a complex land regime has been lacking. The Act was not enacted within the timeline stipulated in the Constitution and has remained bedevilled by the privileging of individual tenure. ${ }^{18}$

As well as the new Constitution, separate legislation created a number of relevant institutions: a Truth, Justice and Reconciliation Commission (TJRC) to investigate human rights violations by the state since Kenya's independence in 1963, a Kenyan National Commission for Human Rights (KNCHR), and a National Land Commission. ${ }^{19}$ The TJRC and KNCHR subsequently reported that "over a period of decades the state discriminated against minority and indigenous communities", predominantly pastoralist, resulting in intercommunal violence, forced displacement, and destruction of the homes and forests upon which traditional livelihoods depended. The state's role in massive dispossession of ancestral lands from pastoralist communities, and its failure to implement judicial decisions protecting minority rights have undermined public confidence in the justice system. ${ }^{20}$ The complex processes at work in such disputes are exemplified in three long-running cases - Endorois, Ogiek and Nubian.

\subsection{The Endorois Case}

The Endorois people officially number some 10,000 (although they claim this is a gross underestimate), and form part of the Kalenjin

17 Community Land Act (27 of 2016), s 14 (3-5).

18 Kenya Constitution 2010, art 261(1). The stipulated timeline was five years, but the Act was enacted one year after that expired. Contrastingly, legislation relating to private land was enacted within the stipulated timeline of 18 months.

19 Truth Justice and Reconciliation Commission Act (6 of 2008). The KNCHR was instituted in 2003, and the 2010 Constitution (Article 59) made it a constitutional body. The NLC was constituted under the National Land Commission Act 2012, the Land Act 2012 and the Land Registration Act 2012.

20 TJRC Report (2013) volume IV; KNHRC Fourth State of Human Rights Report Post-Promulgation 2010-2014. 
tribe (specifically one of five clans of the Tugen sub-tribe) ${ }^{21}$ Their ancestral pastoralist lands around Lake Bogoria (Baringo county in the Rift Valley region) provided them with green pasture and salt licks for their cattle, as well as historical prayer sites, but in 1973 the government gazetted Lake Bogoria as a game reserve, requiring some 400 Endorois families to relocate. ${ }^{22}$ The Kenya Wildlife Service undertook to compensate them with "fertile land" elsewhere, and give them 25 per cent of the tourism revenue and 85 per cent of the jobs generated in the game reserve, but such undertakings were not honoured apart from small compensation payments to some families. A tourist hotel was built beside the lake, and in 1998 the government proposed the area for Unesco World Heritage status (still pending). ${ }^{23}$

In 1997 the Endorois unsuccessfully sought compensation in the High Court from the local county councils still holding the lake land in trust for them, contending that they had occupied and enjoyed undisturbed use of the land since colonial days and before. The High Court held that gazetting the game reserve and paying some compensation extinguished any Endorois land claim, and declined to recognize their communal title or claim to the land, preferring in the judgement consistently to use the term "individuals affected" rather than the whole community. ${ }^{24}$

In 2003 the Endorois petitioned the African Commission for Human and Peoples' Rights (the African Court was not yet constituted) for restitution of their land and compensation for loss suffered. ${ }^{25}$ The Kenyan government responded that the Endorois were not a distinct indigenous community and so could not claim communal land rights and that the county councils administering the trust land regime were entitled to set land aside for purposes that would ordinarily benefit the residents, at which point other interests under African customary law became extinguished. The government also claimed that

21 Kenya Housing and Population Census 2009; Maurice Odhiambo Makoloo and Yash P. Ghai. Kenya: Minorities, Indigenous Peoples and Ethnic Diversity (Minority Rights Group International 2005) 17.

22 Centre for Minority Rights Development (Kenya) and Minority Rights Group (on behalf of the Endorois Welfare Council) $v$ Kenya, African Commission Communication 276/03, para 3.

23 World Heritage Tentative List 1346.

24 William Ngasia and others v Baringo County Council and others, High Court Miscellaneous Civil Case No. 183 of 2000.

25 Communication 276/03. 
compensation had already been paid and that the gazetting of the game reserve minimized Endorois proprietary interests in the land, although rights of access were not extinguished.

In 2010 the African Commission determined differently, that the Kenyan government had violated the Endorois' rights to development, religion and property, and to practise and enjoy their culture. It recommended that the government recognize their rights of ownership, restitute them to their ancestral land, ensure their unrestricted access for religious and cultural practices and cattle grazing, pay adequate compensation for losses suffered and royalties accruing from business activity in the game reserve, register the Endorois Welfare Community, and work with the Endorois on implementation. This was the first ruling by the African Commission recognizing indigenous peoples and their collective rights to ancestral land with related rights to natural resources. It was also the first international ruling on the right to development (under Article 22 of the Banjul Charter and UN Declaration). ${ }^{26}$ Its transformative impact was to "strike at the very heart of trust land regimes by affirming indigenous peoples as active stakeholders - rather than passive beneficiaries - in the management of the resources essential to their socio-cultural and economic survival". ${ }^{27}$

The 2010 Commission decision, however, was only a non-binding recommendation, since when various national-level actors have tried but failed to engage with the Kenyan government. In 2010, the Minister of Lands undertook to ensure implementation but claimed a failure by the AU to notify the decision officially to the government. ${ }^{28}$ In 2012 the government formed a committee comprising the Endorois, an interministerial team, non-state actors, and officers from the Attorney General's office, but no deliberations or findings have been made public. ${ }^{29}$ In 2013 the Endorois returned to the Commission, but the Kenyan government responded that they should go through the Office

26 A/RES/41/128 Declaration on the Right to Development (1986).

27 Cynthia Morel, "Indigenous as Equals under the African Charter: The Endorois Community versus Kenya" in Korir Sing'Oei and Ridwan Laher (eds), Indigenous People in Africa: Contestations, Empowerment and Group Rights (Africa Institute of South Africa 2010); Michael Bollig and David M. Anderson. Resilience and Collapse in African Savannahs. Causes and Consequences of Environmental Change in East Africa (Taylor \& Francis 2017).

28 Parliament of Kenya, Hansard 18 January 2011, 17 (4 June 2014).

29 Interview with the Attorney General's Office, July 2014. 
of the Ombudsman. ${ }^{30}$ In 2014, the President set up a "high-level task force", which was due to submit findings and recommendations by September 2015. ${ }^{31}$ As of August 2018 no findings or recommendations have been made public, nor have the Endorois community benefited from the provisions of the Community Land Act of 2016 on pre-existing customary land rights.

\subsection{The Ogiek Case}

The Ogiek are a hunter-gatherer community officially numbering about 79,000. Like the Endorois, they belong to the Kalenjin tribe but consider themselves to be culturally distinct. ${ }^{32}$ Their ancestral claim relates to the Mau, a closed-canopy forest area that serves as a catchment for 14 rivers and five lakes, including Lake Victoria which is the source of the Nile River and shared between several states. ${ }^{33}$ In 1932 the colonial government gazetted the Mau Forest as a forest reserve to be managed by government forestry agencies, and evictions of Ogiek followed. In 2014, the Ogiek obtained a ruling from the High Court that forcible eviction without resettlement violated their right to life and disrupted their livelihood as hunter-gatherers. ${ }^{34}$ When the High Court directed the National Land Commission to resettle the Ogiek within a year, the government declared it would appeal but apparently has not. ${ }^{35}$

In 2009 the Ogiek filed a communication at the African Commission, which issued provisional measures requiring the Government not to evict them from East Mau Forest. ${ }^{36}$ Because of the government's failure to comply, the case was referred in 2012 to the African Court, which further directed the Kenyan government not to evict. In 2013 the Government compensated some 2000 evicted families but violated the provisional measures when the President lifted a ban

30 Correspondence between the Office of the Ombudsman and the Attorney General, 5 \& 21 September 2013 (accessed from the Office of the Ombudsman.

31 Kenya Gazette Notice no. 6708, 19 September 2014.

32 Kenya Population and Housing Census, 2009; J Kamau, "Ogiek: History of a Forgotten Tribe" http://www.ogiek.org/report/ogiek-ch1.htm accessed 27 July 2018.

33 Republic of Kenya "Report of the Prime Minister's Task Force on the Conservation of the Mau Forests Complex" 2009, 17.

34 Joseph Letuya \& 21 others $v$ Attorney General \& 5 others [2014] eKLR.

35 "Ogiek to wait longer to be resettled" Daily Nation 7 April 2014, 4.

36 African Commission v Republic of Kenya, Application 006/2012 Provisional Measures, 15 March 2013. 
on land transactions in the Mau Forest. ${ }^{37}$ In May 2017 the African Court ruled that Kenya had violated a number of rights for the Ogiek: equal protection and benefit of the law, freedom of religion, right to property, right to cultural life and to promote and protect the community's traditional values, right to freely dispose of their wealth and natural resources, and their right to development. ${ }^{38}$ In November 2017 the government convened another "high-level task force" to examine the African Court and High Court decisions, and recommend measures, but nothing has been made public, and in July 2018 fresh evictions began. ${ }^{39}$

\subsection{The Nubian Case}

This community claims to number about 100,000, descended from soldiers recruited from the Nuba Mountains in Sudan by the British colonial government into the King's African Rifles Regiment around 1900. On completing their service, they did not return to their country of origin but settled in various military camps around Kenya, among them the present-day Kibera (Kibra being a Nubian word meaning forest)..$^{40}$ In 1932 the Kenya Land Commission reported thus:

The legal position of the occupants of Kibera appears to be that they are tenants at will of the crown and the tenancy is liable to termination by the Commissioner of Lands. On the other hand we cannot agree that they have no rights in equity. We consider that

37 Ministry of Devolution and Planning, Special Programmes, Mitigation and Settlement Department, http://www.devolutionplanning.go.ke/ (accessed 27 December 2014).

38 Application No. 006/2012, Judgment, 17 May 2017, para 227.

39 Kenya Gazette Notice No. 10944, 10 November 2017; Reuters Foundation "Hope for evicted forest people as Kenya vows to honour landmark ruling" 1 June 2018; B. Okinda "We are being unfairly targeted in Mau evictions, the Ogiek say", Daily Nation 25 July 2018.

40 C Johanna Sarre, "The Nubians of Kibera 'Revisited': Detribalized Natives, Slum Dwellers, Middle Class?" in David O'Kane, Lena Kroeker and Tabea Scharrer (eds) Middle Classes in Africa: Changing Lives and Conceptual Challenges (Palgrave Macmillan 2018); Samantha Balaton-Chrimes, "The Nubians of Kenya: Citizenship in the Gaps and Margins" in Emma Hunter (ed) Citizenship, Belonging, and Political Community in Africa: Dialogues between Past and Present (Ohio University Press 2016); Christine Bodewes, Civil Society in Africa: The Role of a Catholic Parish in a Kenyan Slum (Cambridge Scholars Publishing 2013). 
the government had a clear duty to these ex-askaris either to repatriate them or to find accommodation for them...In our judgement they ought not to be moved without receiving suitable land elsewhere and compensation for disturbance, and we consider that a similar obligation exists in respect of their widows, sons, who are already householders in Kibera. ${ }^{41}$

The colonial government considered the Nubians to be British protected persons, not citizens, and after independence, the Kenyan government did not grant citizenship and argued that they, therefore, could not lay claim to land in Kenya. ${ }^{42}$ Kibera being public land, no private or community claims should arise, and the government undertook multiple forced evictions, while allowing encroachment by both government and private developers.

In 2003 the Nubian community filed a class action suit in the High Court of Kenya, seeking a declaration of their citizenship status and claiming a violation of other rights, including the right to property. For three years the government delayed the case with procedural obstacles such as requiring the Nubians to produce the identity of all individuals represented in the class action. In 2006 the Open Justice Society and the Institute for Human Rights and Development in Africa (IHRDA) lodged a complaint at the African Commission on behalf of the community. The Kenyan government objected, claiming that the community had not exhausted all local remedies, and sought further adjournments to respond to issues but never did so. In 2015 the Commission determined that the government had violated the community's rights to freedom against non-discrimination, nationality, property and other rights linked to citizenship. It considered that prolonged access, occupation and use of Kibera land by the community entitled them to official recognition and registration of land as community property, and required the government to grant security of tenure, ensure that any evictions in Kibera followed international human rights standards, and inform the Commission of measures taken within

41 Quoted in Nubian Community of Kenya $v$ The Republic of Kenya, African Commission Communication 317/2006.

42 Samantha Balaton-Chrimes, "Indigeneity and Kenyan Nubians: Seeking Equality in Difference or Sameness" (2013) 51 Journal of Modern African Studies 331, 338. 
180 days. ${ }^{43}$ In June 2017, the government, shortly before a general election, issued the Council of Elders of the Nubian community with a title deed for 288 acres of Kibera, although it is unclear if this was responding to the African Commission decision or simply an electoral tactic. $^{44}$

\section{LAW AND POLICY ISSUES RAISED BY THE CASES}

Issues should be examined by courts on a case-by-case basis, taking into account all relevant particularities of the local indigenous issues concerned. ${ }^{45}$ Such was the view of the chair of the International Law Association's Committee on the Implementation of the Rights of Indigenous Peoples, expressed after the lengthy debates over the UN Declaration. The Endorois and Ogiek cases were determined in their favour and greeted with celebrations in Kenya, but much remains unsettled. Before exploring the practical difficulties of implementation, it is appropriate to examine the roles and positions of the key actors in the litigation: the complainant communities, the Kenyan government as respondent, the AU institutions, and the communities' advocates.

The AU working party identified indigenous peoples in Africa as minority groups with a "particular culture, mode of production and marginalized position within the state". ${ }^{46}$ The three communities in the cases constitute collectively less than a quarter of a million people (those numbers disputed) out of Kenya's over 50 million by 2018, and a Pandora's box of similar claims by other communities could now be opened. The TJRC report in 2013 referred to mass displacements of not only the Endorois and Ogiek, but also the ethnic communities of Sengwer, Wataa, Bajuni, Boni, Talai and others, as well as boundary disputes between the Turkana, Pokot, Borana and Somali clans. A parallel can be drawn with the legal status of Gypsies or Travellers in the United Kingdom, official recognition of whose nomadic way of life was adjudicated on a case-by-case basis and ended up being taken to

43 Communication 317/2006 para 171.

44 Open Society Justice Initiative, press release 5 June 2017.

45 Willem Genugten "Protection of Indigenous Peoples on the African Continent" (2010) 104(1) American Journal of International Law 29, 64.

46 WGIP 2005 (fn 5 above) 86. 
the European Court of Human Rights, which urged recognition of their disadvantaged minority status. ${ }^{47}$

Individuals within the communities may need some form of registration to exercise their collective rights. For Kenya, this could raise memories of the much-hated colonial registration of all "native" males over the age of 15 under the kipande system, similar to passlaws in apartheid South Africa, and used to control movement from the native reserves into towns and white settler areas, but repealed after independence. ${ }^{48}$ In Botswana, after successful adjudication of the Basarwa/San case, individuals were still blocked from entering their ancestral land in a national park if their family members had not been named as plaintiffs in the case, or they could not provide identity documents and a hunting licence. ${ }^{49}$ In Nigeria, certificates of indigeneity are issued supposedly to confirm an individual's indigenous status and rights. ${ }^{50}$ If such registration became necessary, it could be provided by the state, or by the community under the principle of "selfidentification". Further complications might arise where some community members have acquired property, some have accepted compensation or been relocated, and constitutional rights of women and children are also engaged.

The Community Land Act 2016 requires communities to be registered and recognized as legal entities for them to administer and manage community land. It creates a two-tier structure, with the community assembly holding overall decision-making power, and the community land management committee responsible for day-to-day functions. ${ }^{51}$ There is so far no sign of this process coming into existence.

47 Robert Home, "Gypsies and Travellers in the United Kingdom: Planning, housing and human rights in a changing legal regulatory framework" (2009) 20(3) Stellenbosch Law Review 533.

48 Anthony Clayton and D. C. Savage, Government and Labour in Kenya, 1895 1963 (Frank Cass 1975); Doug Hindson, Pass Controls and the Urban African Proletariat in South Africa (Ravan Press 1987). The kipande was a metal container hung round the neck with prints of all ten fingers, name, father, district, tribe, location, sublocation, group, clan, circumcision age, signature of official, employer, and detail of wages.

49 https://minorityrights.org/minorities/basarwa, accessed 5 September 2018.

50 Nigeria Research Network, Indigeneity, Belonging, \& Religious Freedom in Nigeria: Citizens' Views from the Street (2014) Policy Brief 7. The Nigerian Federation has 36 states, 300 ethnic groups and more than 300 languages.

51 Community Land Act 2016, ss 6 \& 15. 
By contrast, the Nubian title to the 288 acres (referred to above in section 2) was handed over to the chairman of the Nubian Council of Elders, an entity different and unknown to the provisions of the Act.

The respondent in all the complaints was the government of Kenya, a state party and member of the AU. The late Kenyan politician Tom Mboya pointed to the dangers of fragmentation on the basis of ethnic or community loyalties when he said:

Kenya cannot develop into a nation if all that the leaders do is harp on and magnify the differences that may exist among us ... we are not going to progress if we are going to have hundreds of nations within the nation. ${ }^{52}$

The government of Rwanda, itself the site of mass genocidal killings in 1994, considered that the Indigenous Peoples Declaration:

... established divisive policies and set a bad precedent. It isolated groups and incited them to establish their own institutions alongside existing ones. This would weaken states as a whole and hinder their recovery processes. ${ }^{53}$

The AU working party had criticized the "sort of unity that only reflects the perspectives and interests of certain powerful groups", but state sovereignty remains a pillar of the AU system. ${ }^{54}$ In 1941 Harold Laski wrote of Europe during the Second World War that "it would be of lasting benefit to political science if the whole concept of sovereignty were surrendered" because of both its "dangerous moral consequences" and its "dubious correctness in fact". ${ }^{55}$

In the background was a legal system inherited from colonial days that gave the statewide powers over land. This benefited African elites as it had previously benefited white settlers, with land professionals (surveyors and lawyers particularly) colluding in fraudulent transactions. In 2003 the Ndung'u Commission report documented an estimated two hundred thousand illegal titles created between 1962

52 Debate in Legislative Council of Kenya 19 July 1962, quoted in Julie MacArthur, Cartography and the Political Imagination: Mapping Community in Colonial Kenya (Ohio University Press 2016) 222.

53 Quoted by Genugten (fn 57 above) 35.

54 IWGIA (fn 5 above) 88.

55 Quoted in James J Sheehan, "The Problem of Sovereignty in European History" (2006) 111(1) American Historical Review 1. 
and 2002, mostly after 1986 around election time as political rewards or patronage, and allowing the extended families of the past three presidents to allegedly acquire a tenth of the productive farmlands. ${ }^{56}$

The position of the AU institutions concerned with the complaints is also problematic. The African Commission could only make recommendations, which were routinely ignored by the states affected. ${ }^{57}$ The Commission and Court are located far apart in the vast African continent, and there are practical problems in preparing, submitting and presenting cases. The institutions lack credibility and are criticized as merely barking dogs, and the Court claims difficulties in effectively discharging its mandate where the Executive Council on behalf of the AU Assembly is responsible for monitoring the execution of its decisions. ${ }^{58}$ Implementation requires closer involvement with the member states beyond merely transmitting the judgments and recommendations. ${ }^{59}$ Of the three cases, only the Nubian case, decided by the African Commission and not binding upon Kenya, has been implemented partially. This implies that the character of the decision, whether binding or non-binding, is not the primary factor in implementation, so AU bodies need to explore political motivations for non-implementation.

56 Ndung'u Commission; Aidan Southall, “The Ndung'u Report: Land and Graft in Kenya" (2005) 103 Review of African Political Economy 142; Ambreena Manji, "The Grabbed State: Lawyers, Politics and Public Land in Kenya" (2012) 50(3) Journal of Modern African Studies 467; Catherine Boone, Property and Political Order in Africa: Land Rights and the Structure of Politics (CUP 2014); Ati Onoma, The Politics of Property Rights Institutions in Africa (OUP 2010); Yash Ghai \& Jill Cottrell (eds). Marginalized Communities and Access to Justice (Routledge 2010).

57 Ambe Njoh, "Indigenous Peoples and Ancestral Lands: Implications of the Bakweri Case in Cameroon" in R.Home (ed) Essays in African Land Law (Pretoria 2011) 69.

58 George Mukundi Wachira and Abiola Ayinla, “Twenty Years of Elusive Enforcement of the Recommendations of the African Commission on Human and Peoples' Rights: A Possible Remedy" (2006) 6 African Human Rights Law Journal 466; C Okoloise, "Circumventing Obstacles to the Implementation of Recommendations by the African Commission on Human and Peoples' Rights" (2018) 18 African Human Rights Law Journal 27; CM Fombad, "An Overview of the Crisis of the Rule Of Law in Africa" (2018) 18 African Human Rights Law Journal 213-243.

59 Olafemi Amao, African Union Law: The Emergence of a Sui Generis Legal Order (Routledge 2018). 
The communities' advocates in court were coalitions of human rights NGOs located both within and outside Kenya. The Centre for Minority Rights Development (CEMIRIDE) filed the Endorois case with the assistance of Minority Rights Group International (MRG) and the Centre on Housing Rights and Evictions (a UN organization based in Geneva), supported by the International Network on Economic, Social and Cultural Rights (ESCR-Net), which encompasses more than 230 member organizations. The Ogiek case was brought by CEMIRIDE and Minority Rights International, and the Nubian case by the Open Society Justice Initiative (OSJI) and the IHRDA. The government challenged admissibility and locus standi, and accused the NGOs of being "busy bodies" or "meddlesome interlopers". Such tactics backfired and contributed to unequivocal findings in all three cases, yet retaliatory action by the government closed the KHRC and Africa Centre for Open Governance. In 2017 the IHRDA petitioned the Commission expressing "concern and alarm at the shrinking of the civic society space" in many African countries. ${ }^{60}$ Society can protest by demonstrations and lobbying, but progress depends upon international guidelines, appropriate national laws, and an effective judicial system, while outcomes are affected by resources of plaintiffs and how well cases are presented. ${ }^{61}$

\section{LACK OF IMPLEMENTATION}

A lack of political internalization of the concept of indigenous peoples continues to frustrate implementation, with African governments (not just Kenya) only conceding the narrowest possible interpretation of rulings. State obstructionism in the three Kenyan cases has continued for many years, even though the new land regime after the 2010 Constitution recognized communal land tenure as a form of land ownership equal with other tenure types. It might be expected that an apparently supportive legal framework would ensure implementation but political will is still lacking.

60 IHRDA statement to African Commission, Banjul, 5 November 2017. Kenya ranks 96 out of 180 countries on the Reporters Without Borders (RSF) index of freedom of information (https://rsf.org/en/Kenya accessed 8 October 2018).

61 Franklin Obeng-Odoom and Ransford Edward Van Gyampo, "Land Grabbing, Land Rights, and the Role of the Courts" 37 (2017) Geography Research Forum 127. 
The National Land Commission has many statutory functions, some overlapping, and it remains unclear whether and how some of these may be exercised in implementing the AU judgments. They include the following: to conduct research related to land and the use of natural resources, to encourage the application of traditional dispute resolution mechanisms in land conflicts, develop and encourage alternative dispute resolution mechanisms in land dispute handling and management, ensure that investments in land benefit local communities and their economies, make regulations to prescribe forms of ownership and access to land under all tenure systems, and respect mechanisms of benefit sharing with local communities. ${ }^{62}$ These are indeed fine words, but, as the saying goes, "handsome is as handsome does". The Community Land Act 2016 subordinates management of community land to national laws and policies in relation to various uses: fishing, gathering and hunting, protection of animals and wildlife, water; forestry and environmental protection. It is also unclear how communities and their community land should be defined and registered, especially where the land has been used for "public purposes" before the enactment of the new law. ${ }^{63}$

Even if the government was willing to comply with AU rulings, one should not underestimate the complexity of interpreting judgments from a far-away international court against "facts on the ground" involving ownership, occupation, access and use, and decades of adverse state actions. While the Richtersveld case established that colonial rules did not extinguish customary communal land rights, a "contested genealogy of cartographic practice" still has to be disentangled in such cases. ${ }^{64}$

One particular issue is the term "ancestral lands" used in the judgments in all three cases. Indigenous peoples often describe themselves as custodians or guardians of their ancestral domain or lands. Ancestral land refers to a direct relationship, while ancestral

62 Article 67(2) of the Constitution section 12(3) of the Land Act.

63 Community Land Act 2016 (27 of 2016) Section 38(2); Liz Alden Wily, "The Community Land Act in Kenya: Opportunities and Challenges for Communities" (2018) 7 Land 12; Ambreena Manji, "Whose Land Is It Anyway? The Failure of Land Law Reform in Kenya" (2015) Africa Research Institute Counterpoint 1.

64 David McDermott Hughes, From Enslavement to Environmentalism: Politics on a Southern African Frontier (University of Washington Press 2006); MacArthur (fn 63). 
domain indicates spiritual and cultural relationships beyond material lands and territories. The terms emerged in the 1920s from the International Labour Organization's concern with the situation of indigenous and tribal peoples as workers in the overseas colonies of European powers. ${ }^{65}$ Indonesia and the Philippines now have a legal provision for official certificates of ancestral domain claims and titles. ${ }^{66}$ Kenya's Community Land Act, however, does not even mention "ancestral land". Indigenous peoples sometimes use community mapping methods to identify ancestral land, in which local voices are articulated as appropriate to local needs, interests and goals; the term counter-mapping is also sometimes used as a label for indigenous peoples' mapping struggles against outside forces. ${ }^{67}$

Joint management arrangements can achieve a balance between community land and public interest, and there is relevant experience from other jurisdictions, as has been achieved for Australian indigenous/ aboriginal rights. The success of such joint management depends upon

65 The ILO with the participation of other parts of the UN system created the Indigenous and Tribal Populations Convention (No. 107), adopted in 1957, which preceded the UN DRIP in 2007.

66 The Philippines Constitution (Article 12, Section 5) and the Indigenous Peoples Rights Act of 1997 commit the state to protecting the rights of indigenous cultural communities to their ancestral lands to ensure their economic, social, and cultural well-being. Inter-American Commission on Human Rights, Indigenous and Tribal Peoples' Rights over Their Ancestral Lands and Natural Resources: Norms and Jurisprudence of the Inter-American Human Rights System, OEA/Ser.L/V/II. Doc. 56/09 2010 (Inter-American Commission on Human Rights 2010); Astrid S. Tuminez, Ancestral Domain in Comparative Perspective (United States Institute of Peace 2005); Tri-People Consortium for Peace, Progress and Development of Mindanao, Defending the Land: Lumad and Moro Peoples' Struggle for Ancestral Domain in Mindanao (Tri-People Consortium 1998); Dennis Erasga, "Ancestral Domain Claim: The Case of the Indigenous People in Muslim Mindanao" (2008) 8(1) Asia-Pacific Social Science Review.

67 Nancy Lee Peluso, "Whose Woods Are These? Counter-Mapping Forest Territories in Kalimantan, Indonesia" (1995) 27 (4) Antipode 383; Hugh Brody Maps and Dreams. (Douglas \& McIntyre 1981) and The Other Side of Eden: Hunters, Farmers and the Shaping of the World (Douglas \& McIntyre 2000); Brenda Parker, "Constructing Community through Maps? Power and Praxis in Community Mapping" (2006) 58 (4) Professional Geographer 470. Jiri Panek, How participatory mapping can drive community empowerment - a case study of Koffiekraal, South Africa. (2015) 97(1) South African Geographical Journal, 18; Nate J. Engler, Teresa Scassa, and D.R. Fraser Taylor, "Mapping Traditional Knowledge: Digital Cartography in the Canadian North" (2013) 48 (3) Cartographica 189; Gwilym Lucas Eades, Geoweb: Indigenous Mapping of 
government acknowledgement of the land rights of the indigenous peoples and granting them good standing with the government. A tribunal can adjudicate on claims arising locally. ${ }^{68}$

\section{CONCLUSION}

The Endorois, Ogiek and Nubian cases have been doing the rounds of courts in Kenya and the AU for two decades or so, and the rulings have potentially wide implications for Kenya and indeed the whole African continent. Other indigenous people cases have been adjudicated at the national level, notably in Botswana, South Africa and Uganda, and more may follow in both national and international fora. If such decisions are to be implemented and competing needs balanced, more work is clearly needed. In Kenya, a framework for recognizing and protecting community land rights now exists in the 2010 Constitution, the Community Land Act 2016 and the National Land Commission established in 2013, but there remains a crucial reluctance of political will. Can the colonial legacy as relating to community land rights be reframed and repurposed, or is it a hopeless attempt "to turn fish soup into fish"? What should be the future relationship of state agencies to the ownership or management rights of the communities?

AU institutions could engage more with national governments to create the necessary political will for implementation. There are practical

Intergenerational Knowledge (2010) PhD McGill University; Ragan, Doug, Meghan Muldoon, Jane Bisanju, and others, Community Mapping Guide Volume 3: A Youth Community Toolkit for East Africa. (UNHabitat 2011); Aboriginal Mapping Network http://www.nativemaps.org

68 Megan Davis "Aboriginal Involvement in the Management Of Queensland National Parks and Other Protected Areas" (1999) 6 James Cook University Law Review 29; Jim Birckhead, Laurajane Smith and Terry De Lacy. Aboriginal Involvement in Parks and Protected Areas (Aboriginal Studies Press 1992); Calvin Nhira and Frank Matose, Joint Forest Management and Resource Sharing: Lessons from India for Zimbabwe. (IIED 1996); James Mayers, Incentives for Sustainable Forest Management: A Study in Ghana (IIED 1996); M Rutten, Parks Beyond Parks: Genuine Community-based Wildlife Eco-tourism or Just Another Loss of Land for Maasai Pastoralists in Kenya? (IIED 2002); W Astle, A History of Wildlife Conservation and Management in the Mid-Luangwa Valley, Zambia (British Empire and Commonwealth Museum 1999); Maitseo Bolaane, Chiefs, Hunters and San in the Creation of the Moremi Game Reserve, Okavango Delta: Mulitracial Interactions and Initiatives, 1956-1979. (National Museum of Ethnology Osaka 2013). Ben Gardner, Selling the Serengeti: The Cultural Politics of Safari Tourism (University of Georgia Press 2016). 
examples from the UN system where special procedures have included technical assistance to governments on the implementation of their recommendations. ${ }^{69} \mathrm{AU}$ institutions could engage more with national governments to create the necessary political will for implementation. There are practical examples from the UN system where UN special procedures have offered technical assistance to government actors in the implementation of recommendations. ${ }^{70}$ Technical assistance at government level should be complemented with initiatives targeting domestic constituencies such as the indigenous communities: for example, the Nubian community used their electoral leverage to pressurize the government for at least partial implementation of the ruling in their favour.

The AU in 2009 adopted a Declaration on Land Issues, and Guidelines on Land Policy followed in partnership with the UN Economic Commission for Africa and the African Development Bank, supported by the World Bank and other international agencies. Since the AU's Constitutive Act stresses the sovereignty of its member states, the guidelines were careful to state that they were not a normative framework intended to be binding upon member states, nor a draft land policy for their adoption, nor instruction for specific country situations. Yet some prescriptive language was used, such as the "overwhelming presence of the State in land matters must change". ${ }^{71}$ It is necessary to generate and disseminate relevant knowledge, both from AU institutions and the academia, that can strengthen the capacity and institutions concerned with land.

Disputes over land and property are notorious for creating complex and interminable legal proceedings, and the scope for alternative dispute resolution has been recognized in Kenya's new land laws. Such hybrid forms of judicial administration alongside the main court system may

69 Faith Njoki Kabata, "Impact of International Human Rights Monitoring Mechanisms in Kenya" (LLD thesis, University of Pretoria 2015) 262.

70 See discussion in Faith Njoki Kabata "Impact of International Human Rights Monitoring Mechanisms in Kenya" (LLD thesis University of Pretoria 2015) 262-263.

71 AU Declaration on Land Issues and Challenges in Africa, Assembly/AU/Decl.1 (XIII) Rev.I; R Home "Land and the Right to Development in Africa" in C C Ngang et al (eds) Perspectives on the Right to Development (2018); AU "Declaration of Land Issues and Challenges: A Review of Progress Made". A report to the conference of Specialized Technical Committee on Agriculture, Rural Development, Water and Environment, (2017), para 6. (section 2.1). 
be held near where the disputes arise, and may be quicker and cheaper than the courts, addressing largely factual rather than legal issues, such as status of private titled lands, and the implications where private owners are or are not members of the community, or where titles had been improperly obtained? Other issues are what compensation was paid previously, who were the beneficiaries, and should there be retrospective revaluations? Where land claimed as ancestral land by communities is also officially public land (as with forests and wildlife reserves in the Ogiek and Endorois cases respectively), how can the interests be reconciled? While Kenya's Community Land Act is silent on the matter, other jurisdictions offer good practice examples, and the solution lies in joint management programmes in which the communities and government participate in the conservation of national natural resources on community land. The way forward is for the Kenyan government to develop joint management arrangements that allow the Endorois and the Ogiek to access, use and manage resources in the Lake Bogoria region and Mau Forest, respectively, while conserving those resources for public benefit.

The challenges are serious but not insuperable. Legal and institutional solutions can be found, and global knowledge is being produced in this area which needs to be shared for the benefit of all, offering a re-alignment of the relationship between the state and its citizens around their collective and composite rights to development. 